\title{
PERFORMANCE OF BIOCLIMATIC ARCHITECTURE IN BUGIS VERNACULAR HOUSING: A CASE STUDY OF JIDA AND LAMMADA HOUSES
}

\author{
Agung Murti Nugroho \\ Department of Architecture, University of Brawijaya, Jl. MT Haryono No 167 Malang, INDONESIA \\ Email: agungmurti@ub.ac.id
}

\begin{abstract}
Bioclimatic architecture is composed of climate-responsive knowledge in vernacular buildings as an effort to create comfortable conditions. This study aims to evaluate the suitability of the application of bioclimatic design to the performance of the thermal environment in one type of Bugis house. The method used is visual assessment and measurement of temperature and humidity in the case studies of Jida and Lammada houses, South Sulawesi. The results of visual observations show the accuracy of the bioclimatic design on the volume and slope elements of the roof, wall type and material, floor height, and shade tree layout. The performance of the thermal environment in the living room and bedroom of Lammada house is better than similar rooms at Jida house. The bioclimatic elements that affect the performance of the thermal environment are the volume of the roof, the type and material of the walls, and the height of the floor.
\end{abstract}

Keywords: Bioclimatic; Bugis vernacular housing; thermal environmental comfort.

\section{INTRODUCTION}

The crisis of climate change, depletion of the ozone layer, limited energy sources, and increased carbon emissions have awakened the building and construction industry to apply the concept of sustainnable development. The development of new settlements in the context of sustainable development must always consider the balance of providing quality of life, economic growth, and protection of the local natural environment. The house as a human habitation should bring together aspects of sustainable development and the preservation of the built environment with the main indicators being the comfort of living and low energy consumption. People could learn from the vernacular house, which makes climate-responsive design a major consideration. Climate responsive design in vernacular buildings is known as bioclimatic or architecture that adapts to the local climate. Bioclimatic architecture is an example of the use of passive designs to achieve thermal comfort with the use of energy and carbon emissions to a minimum.

The criteria for bioclimatic architecture, especially in the tropical islands, have been formulated by previous research, including orientation aspects that stretch west-east (Prasetyo, 2016; Beccali et al., 2018) and wind direction (Manzano-Agugliaro et al., 2015; Nguyen et al., 2019); lean mass composition and the presence of a veranda (Nguyen et al., 2011; Nugroho, 2012); a roof with a large volume and slope, lightweight materials, roof openings, wide eaves (Victoria et al., 2017; Daemei et al., 2019); thin walls made of light materials (Prasetyo \& Astuti, 2017; Hildegardis et al., 2019), porous type walls (Nugroho, 2012; Nugroho, 2018), adequate placement and size of openings (Beccali et al., 2018; Nugroho, 2019); stage floor with a certain height and light material (Victoria et al., 2017; Zune et al., 2020); landscaping with shade plants and placement on the west side ( Nugroho, 2018; Daemei et al., 2019). Such criteria continue to develop as new studies on vernacular bioclimatic architecture prevail in the tropics.

The dynamics of climate change, such as solar radiation, rainfall, and wind conditions, have an impact on various bioclimatic adaptations in vernacular houses in Indonesia. The form of a vernacular house in an area is influenced by the location and character of its natural environments, such as coastal, plains, or mountains. One example of a vernacular house in the coastal area is the Bugis house. Bugis houses are built using natural materials found in the surrounding environment and are designed as protection against hot and humid climatic conditions. Bugis vernacular houses are known for their adaptation to the climate with a passive design strategy that is able to provide thermal comfort (Abdullah et al., 2013). Such a form of adaptation can still be found and survives to this day, one of which is in Mattiro Ade Village, Pinrang Regency, South Sulawesi Province. There are two types of Bugis vernacular houses known as Jida House and Lammada House. The two houses have a close position, are in the lowlands and are influenced by the coastal climate, which has high temperature and humidity. The condition of the two houses is still 
livable and well maintained, despite changes in roof material replacement and impacts on the performance of the thermal environment. Such changes are not based on past empirical knowledge, which is the result of a continuous process of inventing for a comfortable stay. Knowledge of bioclimatic design and its effect on thermal environmental performance is important to study through thorough research on Bugis vernacular dwellings with case studies of Jida house and Lammada house.

\section{METHODOLOGY}

The research phase contains two main stages, i.e., visual assessment and measurement of the thermal environment with qualitative and quantitative approaches. Additionally, visual assessment answers whe- ther the application of bioclimatic design elements is appropriate. Meanwhile, the measurement of the thermal environment draws on the level of suitability of air temperature and humidity conditions and the performance of decreasing air temperature (Fig. 1).

The location of the research object is geographically located $3^{\circ} 44^{\prime} 54^{\prime \prime}$ south latitude and $119^{\circ} 37^{\prime}$ 42" East longitude (Fig. 2). Climatic conditions are influenced by a tropical monsoon climate with an average temperature and humidity of $28^{\circ} \mathrm{C}$, and $82 \%$, and the wind direction tends to be from the west and northwest. The two case studies function as a housing with the same shape, which is rectangular and consists of three parts: (1) the base or under the house (awa bola); (2) the middle part (alle bola), and (3) the top (rakkeang). The orientation of the two houses is southeast-northwest and consists of two bedrooms and

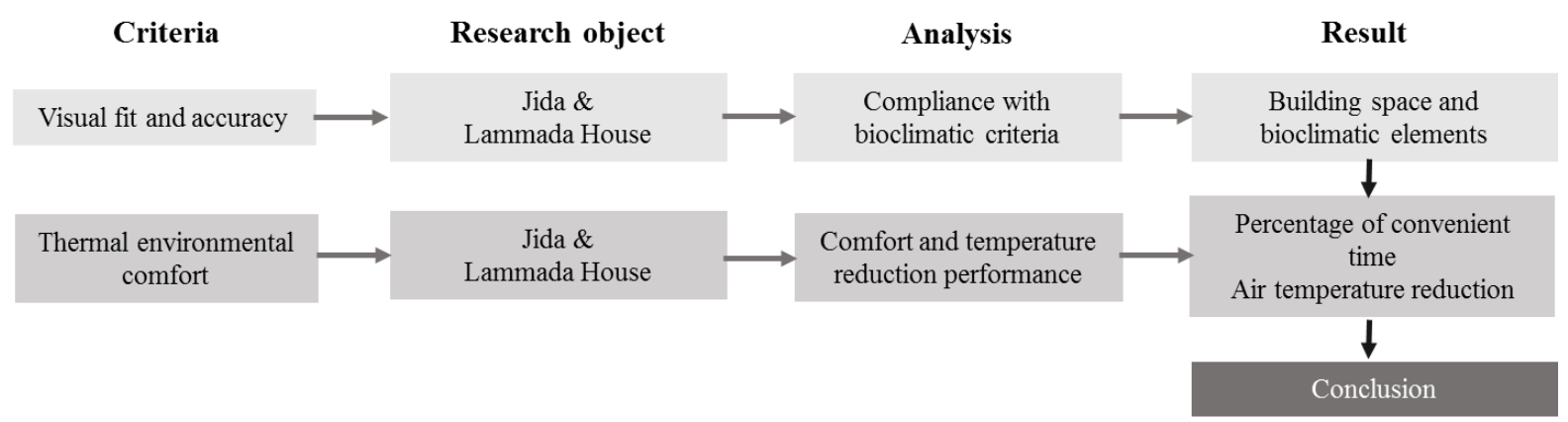

Fig. 1. Research Stages

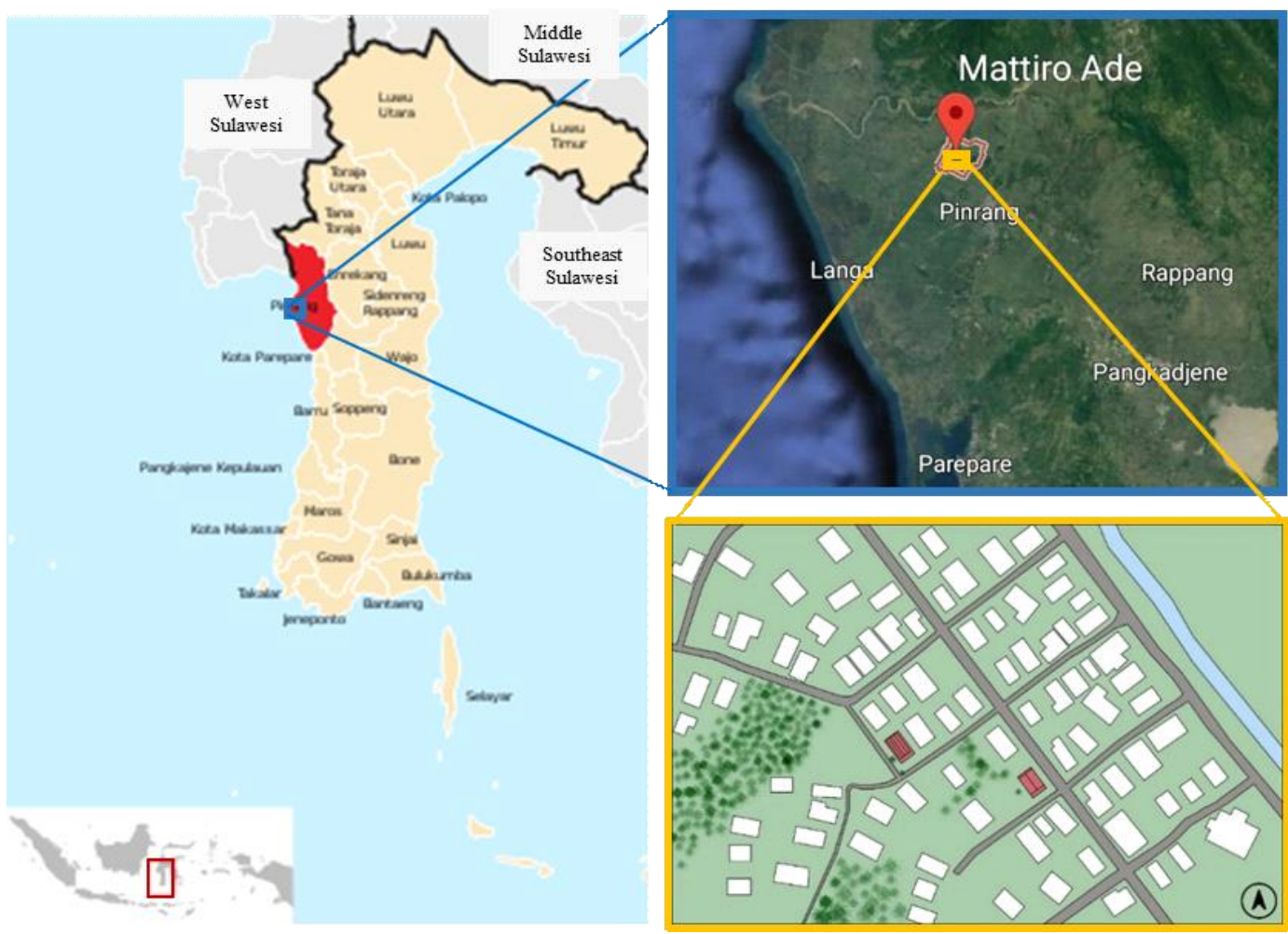

Fig. 2. Location of research case studies (Source: Images acquired from Wikipedia, Google Earth and author). 

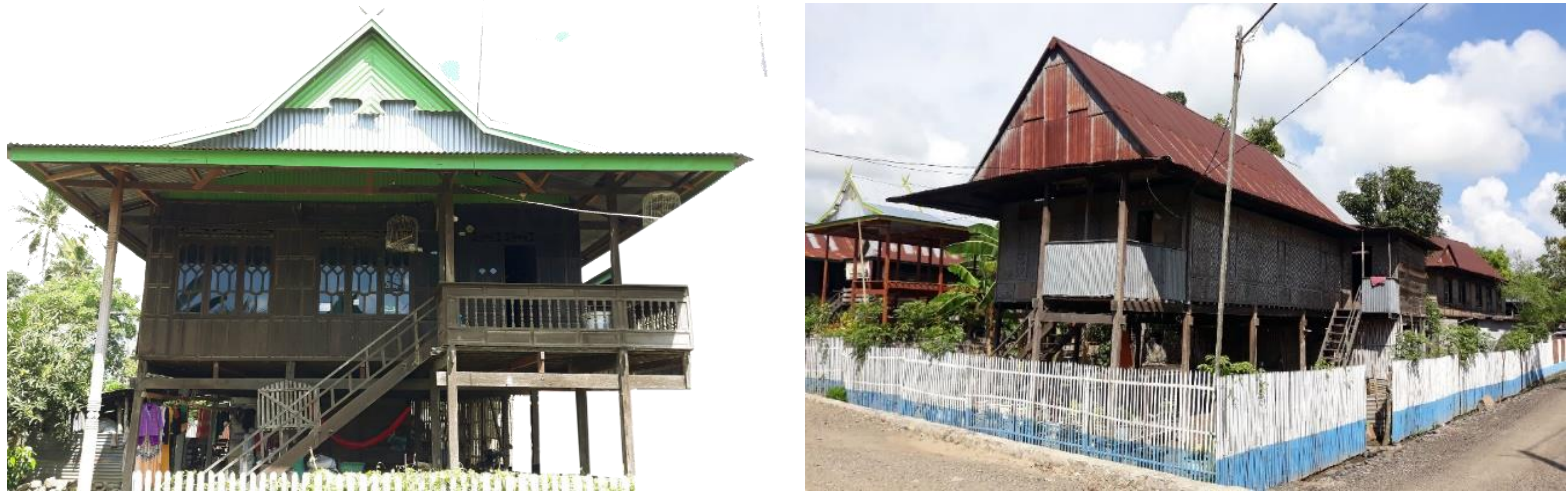

Fig. 3. Jida House (left) and Lammada House (right)

a living room, which is directly adjacent to the kitchen. The roof of the house is in the form of a gable, with each side having an overhang with a width of 1 meter, especially at the front, which functions as a terrace (Fig. 3).

The neutral temperature as a reference for the comfortable temperature limit for the local area is calculated based on the average monthly air temperature over the last few years. The use of climate data uses data from the nearest BMKG station, called the Paotere Maritime Meteorology Station. Based on the equation of Humphreys and Auliciem (Nugroho, 2018), the neutral temperature obtained is $26,3^{\circ} \mathrm{C}$ based on formula $17,6+(0,31 \times$ monthly average temperature). Comfortable temperature ranges of $5^{\circ} \mathrm{C}$, i.e., $2.5^{\circ} \mathrm{C}$ up and down, making the comfortable temperature limit $23.8^{\circ}-28.8^{\circ} \mathrm{C}$ as described in Fig. 4.

Visual data in the form of all building elements related to bioclimatic design included roofs, spaces, walls, floors and landscaping. Measurements of air temperature and humidity were carried out at four points in each house and one point in the outside environment of the building. The four points are the roof, under, living room and bedroom with the placement as shown in Fig. 5. The tool used is a hobo data logger type temperature and humidity of RC $4 \mathrm{HC}$ with accuracy up to $0,1^{\circ} \mathrm{C}$ and $1 \%$. Data recording was conducted every 15 minutes for one month. Data collection was carried out from February 16 to March 16, 2019.

Analysis of the results of visual observations shows an assessment according to the level of conformity between the architectural elements that exist in each house with bioclimatic design criteria. Analysis of the measurement for the thermal environment is done by evaluating the average temperature and humidity every hour in a month, the maximum and minimum values associated with time, and comparison with the comfortable temperature limit and the performance of decreasing air temperature. Further, the discussion compares the results between visual observations, measurements, and previous studies, highlighting the significance of the relationship between the three is obtained.

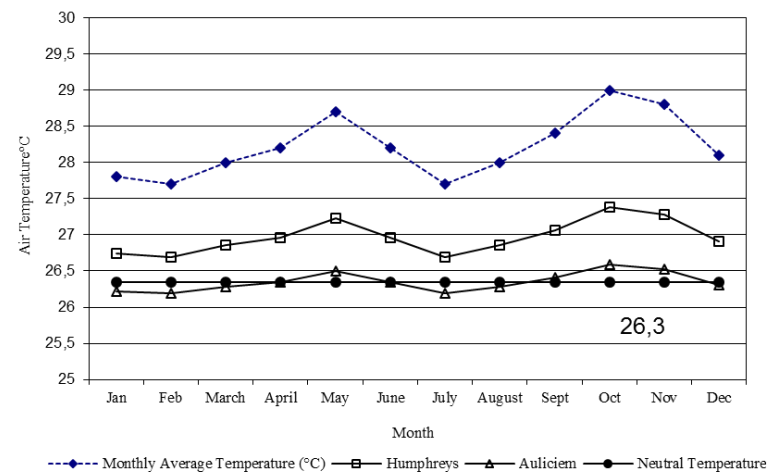

Fig. 4. Neutral temperature and comfortable temperature limits in the thermal environment of the study object Average

\section{RESULTS AND DISCUSSION}

\section{The Suitability of Bioclimatic Elements in Jida and Lammada Houses}

Jida house is a type of house on stilts with a floor area of about $95 \mathrm{~m}^{2}$ with a size of $7 \mathrm{~m} \times 13 \mathrm{~m}$ and has been Jida house is a type of house on stilts with a floor area of about $95 \mathrm{~m} 2$ with a size of $7 \mathrm{~m}$ x13 m and has been around for \pm 30 years. The roof is in the form of a saddle with a slope of $45^{\circ}$ and uses zinc material. The walls of the house are 2.5 meters high with 15-20 $\mathrm{mm}$ thick wooden planks arranged vertically on the front and horizontally on the sides and back. Twelve glass windows surround the building with a size of 60 $\mathrm{cm} \times 110 \mathrm{~cm}$. The floor of the building is located 2.5 meters above the ground, made of wooden planks with the same thickness as the walls.

Lammada house is an older type of Bugis vernacular house built more than fifty years ago. The floor area of the building is about $74.5 \mathrm{~m} 2$ with a size of $6 \mathrm{mx} 11 \mathrm{~m}$. The roof of the building is in the form 


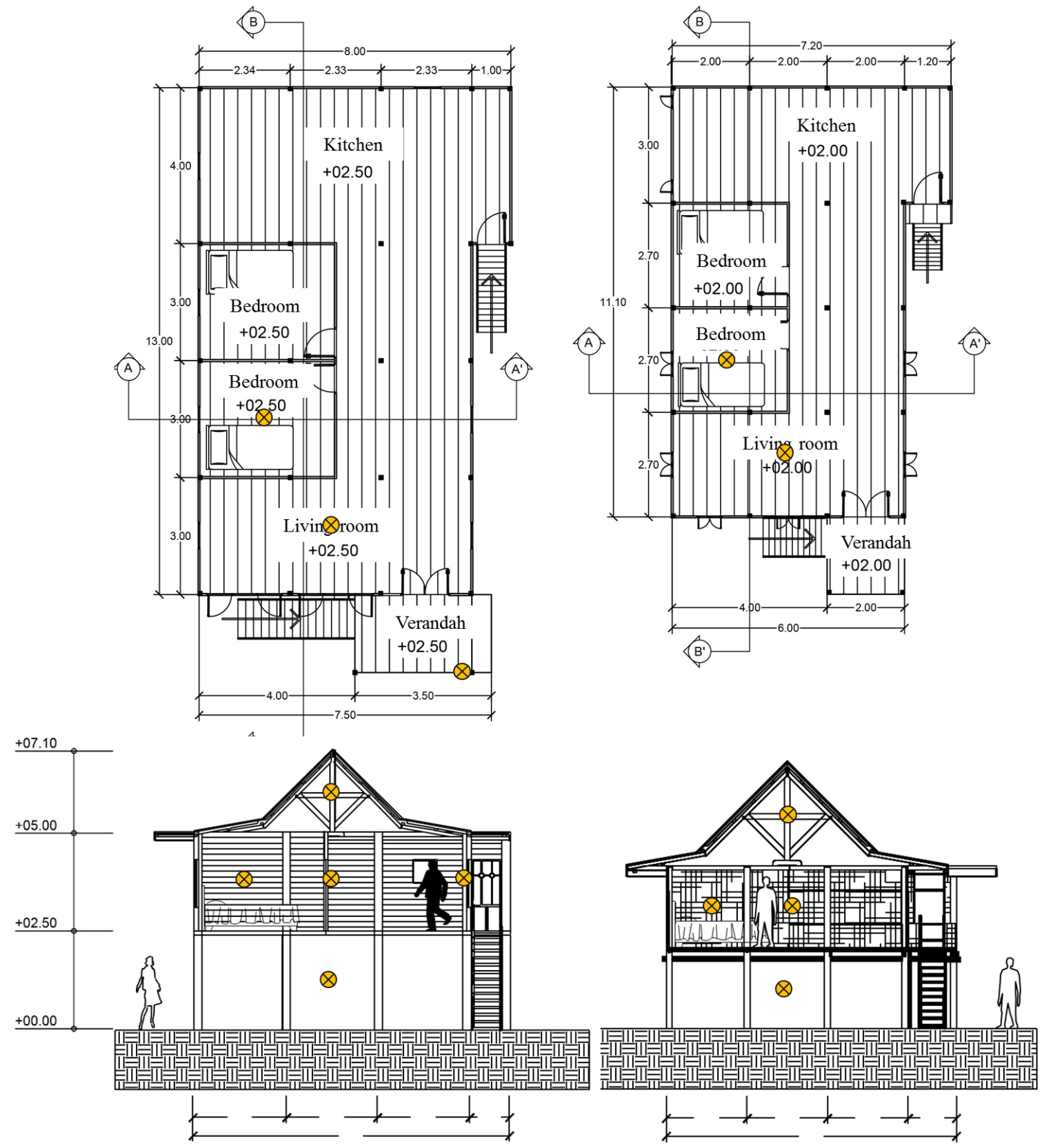

Fig. 5. Position of the Hobo Data Logger Tool

of a saddle that used to use thatch material and has now been replaced with zinc material with a slope of $45^{\circ}$. The height of the walls of the building is 2 meters with a thickness of less than $5 \mathrm{~cm}$ and uses woven bamboo material. There are eight windows with a size of $60 \times 80 \mathrm{~cm}$, and the shutters use woven bamboo material. The floor has a height of 2 meters above the ground using wooden planks.

Visual assessment of Jida House and Lammada House refers to the criteria for bioclimatic architecture in vernacular buildings as in table 1 . Based on field observations, there are similarities between Jida House and Lammada House so that they have the same level of suitability for the application of Bioclimatic Architecture. The same sub-criteria include the orientation that extends southeast-northwest, the direction towards the dominant wind, the proportion of building width-length, the optimal width of the building, the presence of a front porch, roof material, and landscape layout. The orientation of the longitudinal direction of the buildings of the two houses is quite appropriate because they are not right in the west-east direction. This will have an impact on the spaces on the west side of the building, i.e., the bedroom. The direction facing the building forms an angle of $45^{\circ}$ to the wind from the west, while when the wind direction is from 
the northwest, the airflow is not maximal into the two buildings. The proportion of the width-length of the building is related to the lean building mass criteria for the tropics (1:3). Jida house and Lammada house each have almost the same proportion, i.e., 1: 1.8, so they are quite appropriate because they are still rectangular. The optimal width of buildings in the tropics is related to the height of the room, which is a maximum of four times the height of the room (Nugroho, 2018). The widths of Jida House and Lammada House are 7 meters and 6 meters, respectively, at the height of 2.5 meters and 2 meters. So that the optimal building width, both houses are in accordance with the criteria. The existence of terraces in both buildings also has the same position on the front of the southeast side, which is thermally in a comfortable position. Both houses use the same roofing material, i.e., zinc without any roof opening elements. This results in a lack of compliance with bioclimatic criteria. The last criterion related to the similarities between the two houses is the layout of the plants that are both placed on the west side of the building so that it is in accordance with the Bioclimatic criteria, i.e., the west side of the building in the tropics requires more protection against solar radiation than the other side of the building.

There are two sub-criteria that have the same value but have different levels of performance based on numerical calculations. The first sub-criterion is the aspect of openings, in which both Jida and Lammada houses have an adequate number of window openings, 12 and 8, respectively. However, Jida house has a higher performance based on the percentage of window openings to the wall area. The percentage of window openings is $7.92 \%$, while the Lammada House is $5.65 \%$. The second sub-criteria is the height of the stage floor, which is considered appropriate. However, Jida house has a height of $50 \mathrm{~cm}$ greater than Lammada house.

The difference in the level of suitability of the criteria for Bioclimatic Architecture in Jida House and Lammada House is in the sub-criteria of volume and roof slope, type and material of walls, and types of shade trees. Based on the calculation of the volume of the roof, it was found that the Lammada House has a volume of $33 \mathrm{~m} 3$ while the Jida House is $29.9 \mathrm{~m} 3$. Although the difference is not too large, when compared to the volume of the residential space below, there is a significant difference in the percentage between the volumes of the roof compared to the volume of residential space. The percentage of the roof volume of Lammada house is $25 \%$ of the volume of residential space, while at Jida house, it is only $13 \%$. The difference in the volume of the roof is influenced by the difference in the slope of the roof on

Table 1. The results of the assessment of the level of conformity of the criteria for bioclimatic architecture in the case study

\begin{tabular}{|c|c|c|c|c|}
\hline Criteria & Bioclimatic sub criteria & Jida House & Lammada House & Notes \\
\hline \multirow[t]{2}{*}{ Orientation } & $\begin{array}{l}\text { Orientation is generally elongated or } \\
\text { longitudinal west-east }\end{array}$ & Longitude Southeast-Northwest & $\begin{array}{l}\text { Longitude Southeast- } \\
\text { Northwest }\end{array}$ & - \\
\hline & Against the wind & $\begin{array}{l}\text { Not facing the main wind } \\
\text { direction }\end{array}$ & $\begin{array}{l}\text { Not facing the main wind } \\
\text { direction }\end{array}$ & - \\
\hline \multirow[t]{3}{*}{ Time and space } & Mass proportion widthlength $1: 3$ & $\begin{array}{l}7 \text { meters wide, } 13 \text { meters long: } \\
1: 1.8\end{array}$ & $\begin{array}{l}6 \text { meters wide, } 11 \text { meters } \\
\text { long: } 1: 1.8\end{array}$ & - \\
\hline & $\begin{array}{l}\text { Maximum building width is } 12 \\
\text { meters } / 3 \mathrm{x} \text { the height of the room }\end{array}$ & Width $3 \mathrm{~m} \times 2.5 \mathrm{~m}=7.5$ & Width $3 \times 2$ meters $=6$ & - \\
\hline & A terrace or veranda & Front terrace 1 meter wide & Front terrace 1 meter wide & - \\
\hline \multirow[t]{3}{*}{ Roofing } & $\begin{array}{l}\text { Roof volume and comparison with } \\
\text { occupancy volume }\end{array}$ & $\begin{array}{l}\text { Volume } 29.9 \mathrm{~m}^{3} \text { Ratio to space } \\
\text { volume }=1: 7 \text { or } 13 \%\end{array}$ & $\begin{array}{l}\text { Volume } 33 \mathrm{~m}^{3} \\
\text { Ratio to space volume= } 1: 3 \\
\text { or } 25 \%\end{array}$ & $\begin{array}{l}\text { Lammada house has } \\
\text { a larger volume }\end{array}$ \\
\hline & Steep roof slope & Tilt angle $45^{\circ} \& 15^{\circ}$ & Tilt angle $\pm 45^{\circ}$ & - \\
\hline & Light material & Tin & Tin & - \\
\hline \multirow[t]{3}{*}{ Walls } & Wall type & $\begin{array}{l}\text { Only one type, i.e., the wall } \\
\text { ventilation openings }\end{array}$ & $\begin{array}{l}\text { Two types, wall opening } \\
\text { and porous woven bamboo }\end{array}$ & - \\
\hline & Material conductivity & $\begin{array}{l}\text { Wooden Board, low without } \\
\text { ventilation }\end{array}$ & $\begin{array}{l}\text { Woven Bamboo, low with } \\
\text { ventilation }\end{array}$ & $\begin{array}{l}\text { Lammada house has } \\
\text { lower material } \\
\text { conductivity }\end{array}$ \\
\hline & $\begin{array}{l}\text { Number and size of Apertures/ratio } \\
\text { of openings to walls }\end{array}$ & $\begin{array}{l}12 \text { windows around the building } \\
\text { measuring } 60 \mathrm{~cm} \times 110 \mathrm{~cm} \text {. The } \\
\text { ratio there is a wall of } 7.92 \%\end{array}$ & $\begin{array}{l}8 \text { windows around the } \\
\text { building measuring } 60 \mathrm{~cm} \mathrm{x} \\
80 \mathrm{~cm} \text {. Ratio to wall } 5.65 \%\end{array}$ & $\begin{array}{l}\text { Jida House's opening } \\
\text { ratio is bigger }\end{array}$ \\
\hline \multirow{3}{*}{$\begin{array}{l}\text { Floor and } \\
\text { Landscape }\end{array}$} & Stage height & 2.5 meter & 2 meter & Jida House's floor \\
\hline & Presence of shade plants & There is a mango shade tree & Non-existent & $\begin{array}{l}\text { Jida house has a } \\
\text { shade tree }\end{array}$ \\
\hline & Plant position & West side & West side & - \\
\hline
\end{tabular}


the two houses. A Jida House has two variations of the roof slope, i.e., $45^{\circ}$ and $15^{\circ}$, while Lammada House has only one roof slope, which is $45^{\circ}$. This is the basis for assessing the level of suitability of the roof subcriteria (volume and slope). The Bioclimatic of Lammada house is better than Jida house.

The types of walls and materials in Jida House and Lammada House have similarities with the number of window openings, but the difference is in the type of window. Lammada House window openings use woven bamboo shutters, while Jida House uses glass material. So that the overall walls of Lammada house include the type of porous wall (breathing) while at Jida house, it is only limited to walls with openings. The use of wall materials in both houses has the same low conductivity level, as it is easy to absorb and release heat. This property is very suitable in the tropics but with the condition that there is always a flow of air that dissipates heat. Lammada houses that apply a porous ventilation system have a better performance in dissipating heat in the wall material. In contrast to the placement of the same shade trees in both houses, there are different types of shade trees used, i.e., mango trees for Jida house and banana trees for Lammada house. Based on the type of tree, Jida house has a higher suitability level than that of Lammada house (Fig. 6).

Based on the results of the assessment of the level of conformity with the criteria for Bioclimatic Architecture, it was found that the Lammada House had a higher suitability than the Jida House, especially on the sub-criteria of volume and roof slope as well as the type and material of the walls. Meanwhile, Jida house has more value in the selection of shade plants.
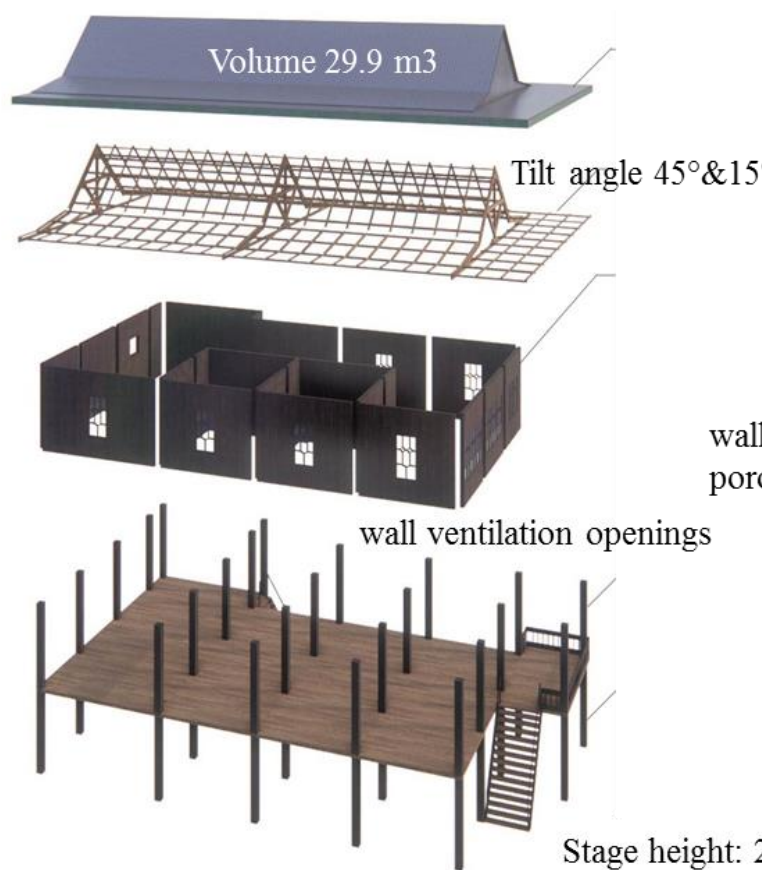
porous woven bamboo

\section{Thermal Environmental Conditions in Jida House and Lammada House}

The thermal environmental conditions at Jida House and Lammada House can be explained in Figs. 7 and 8. The graph in the figure is a graph of air temperature and humidity obtained by finding the average hourly for one month of measurement, for example, data at 12.00 which shows the air temperature of the roof space of $37.9^{\circ} \mathrm{C}$. This means that the value is obtained from the results of the average air temperature measurement in the roof space within the same hour for one month. The temperature and humidity conditions in the Jida House can be explained based on Fig. 7. The outdoor temperature as a reference for the thermal environmental conditions shows an average air temperature of $27.9^{\circ} \mathrm{C}$ with a maximum air temperature of $32.9^{\circ} \mathrm{C}$ at 12.00 and a minimum air temperature of $24.2^{\circ} \mathrm{C}$ at 06.00 . The maximum and minimum air temperature range is $8.7^{\circ} \mathrm{C}$ which shows that there is a relatively large difference in air temperature between day and night.

The air temperature condition at Jida House shows that the highest average temperature is in the bedroom at $29.2^{\circ} \mathrm{C}$, followed by the living room, roof room and under room, each at $29.1^{\circ} \mathrm{C}, 28.9^{\circ} \mathrm{C}$, and $26.5^{\circ} \mathrm{C}$ respectively. The position of the bedroom on the west side of the building is one of the contributing factors. The maximum and minimum air temperatures occur in the roof space, i.e., $37.9^{\circ} \mathrm{C}$ and $23.7^{\circ} \mathrm{C}$ at 12.00 and 06.00. The maximum and minimum air temperature range of $14.3^{\circ} \mathrm{C}$ that occurs in the roof space is influenced by zinc material which easily
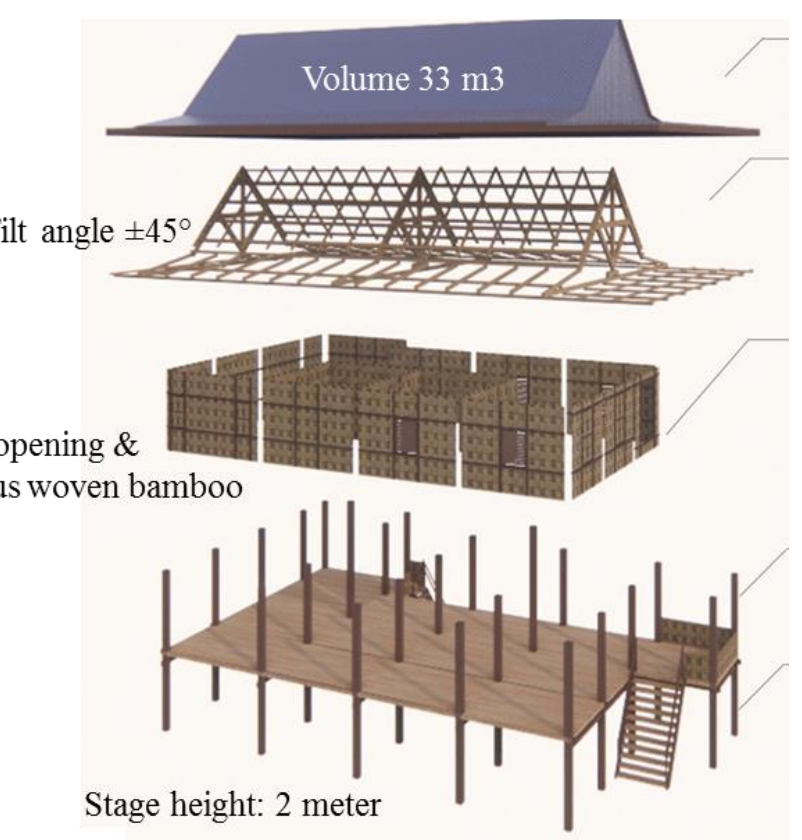

Fig. 6. Comparison of the criteria for bioclimatic architecture between Jida House (left) and Lammada House (right) 
absorbs heat. The column space in Jida House shows a low maximum and minimum air temperature ranges $\left(5.4^{\circ} \mathrm{C}\right)$, meaning that it has stable air temperature performance. This can be understood because the position of the space under is relatively protected.

The air temperature condition in Lammada House shows that the highest average temperature is in the roof room at $30.2^{\circ} \mathrm{C}$ followed by the living room, bedroom and under room, each at $28.8^{\circ} \mathrm{C}$, $28.4^{\circ} \mathrm{C}$, and $27.4^{\circ} \mathrm{C}$ respectively. The shape of the large roof and shading the space below is one indication that the roof space has the highest air temperature. The maximum and minimum air temperatures also occur in the roof space, i.e., $40.3^{\circ} \mathrm{C}$ and $24.4^{\circ} \mathrm{C}$ at 12.00 and 06.00 with an air temperature range of $15.9^{\circ} \mathrm{C}$. The influence of the position of the roof and the use of zinc material that easily absorbs and releases heat is one of the causes of this condition. The room under the Lammada House, in addition to showing the lowest average temperature, also has a low maximum and minimum air temperature range, which is $5.9^{\circ} \mathrm{C}$. This figure is $0.5^{\circ} \mathrm{C}$ higher than the space under the Jida House.

The air humidity in the outdoor room shows an average number of $89.3 \%$ with a maximum and minimum value of $99.1 \%$ and $71.5 \%$ at 06.00 and 12.00 or the opposite time with the air temperature component. The range of maximum and minimum air humidity is $27.6 \%$, which gives an indication of quite large fluctuations in the rate of water evaporation. The highest average air humidity in Jida House is in the basement room at $88.7 \%$ followed by the living room, bedroom and roof space of $86 \%$ each, $85.1 \%$, and $83.4 \%$. The space under the building, which is directly related to the ground, is one of the causes of high humidity. Maximum and minimum air humidity occurred in the roof space of $99.5 \%$ and $56.2 \%$ at 06.00 and 12.00 hours as well as the outdoor space with a larger range (43.3\%). The lowest air humidity range is in the basement room (17.4\%), this indicates that it has a more stable thermal environment than other rooms. However, the comfortable number for air humidity $(40 \%-60 \%)$ is only found in the time duration from 11.00 to 14.00 . As with the humidity in the Jida House, the highest average humidity in the Lammada House is in the under room at $92.3 \%$ followed by the living room, bedroom and roof space of $87.3 \%$ each; $86.6 \%$ and $75.7 \%$, respectively. The maximum and minimum air humidity occurred in the under and roof spaces of $99.2 \%$ and $48.72 \%$ at 06.00 and 12.00 , respectively. The lowest range of air humidity is in the basement (17.7\%), while the largest range is in the roof space (44.7\%). The humidity figure in the residential area of Lammada house shows a value that is beyond comfortable limits throughout the day.

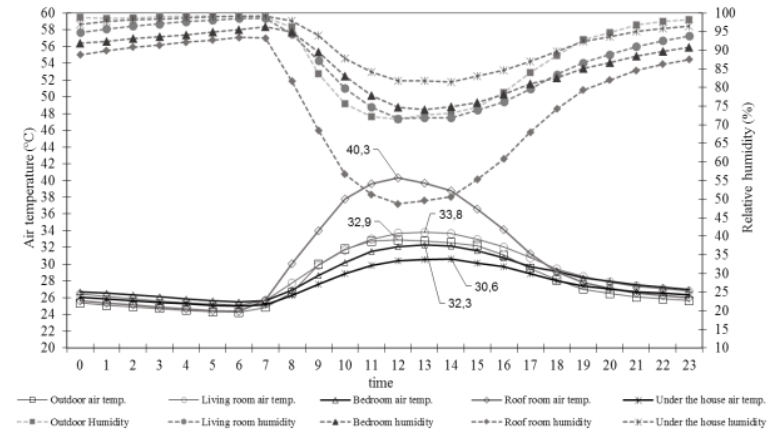

Fig. 7. Comparison of Air Temperature and Humidity in Outdoor Room, Living Room, Bedroom, Roof Room and Under House Jida

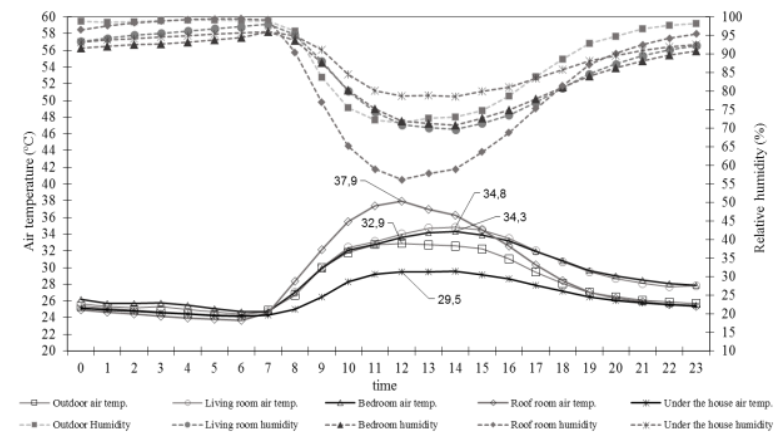

Fig. 8. Comparison of Air Temperature and Humidity in the Outdoor Room, Living Room, Bedroom, Roof Room and Room Under Lammada House

The performance of comfortable air temperature at Jida house and Lammada house is based on a neutral temperature or a comfortable temperature at the location, which is $26.3^{\circ} \mathrm{C}$ with the comfort zone limit between $23.8^{\circ} \mathrm{C}-28.8^{\circ} \mathrm{C}$. The outdoor air temperature which is within comfortable limits ranges from an air temperature range of $24.2^{\circ} \mathrm{C}$ to $28.1^{\circ} \mathrm{C}$ in the morning until 08.00 and in the afternoon starting at 18.00. The comfortable temperature lasts at night with a comfortable temperature of 15 hours, while during the day it is above the comfortable temperature with an average of $31.7^{\circ} \mathrm{C}$ (Figs. 9 and 10).

The largest percentage of the long comfortable air temperature in the Jida House is in the under room by $79 \%$ or 19 hours of the total 24 hours (Fig. 9). The uncomfortable time in the basement occurs from 11.00 to 15.00 with the average uncomfortable air temperature at that time of $29.4^{\circ} \mathrm{C}$. Bedrooms at Jida House have the largest percentage in uncomfortable conditions, i.e., $50 \%$ per day with an average uncomfortable air temperature of $32.1^{\circ} \mathrm{C}$ from 09.00 to 21.00. Things that are not much different also occur in the living room with an uncomfortable time difference of one hour. The air temperature in the roof space follows the comfortable air temperature of the outdoor space for its duration with an average uncomfortable 
air temperature of $3.1^{\circ} \mathrm{C}$ higher. This is in accordance with the calculation of the difference in peak air temperature where there is no time difference between the outdoor space, the roof space and the under room. Dili et al, (2011) argues that the difference in the time of peak air temperature determines the time lag of building materials. The living room and bedroom at Jida House have a time difference between the peak air temperature and the outside space of 2 hours. As far as materials are concerned, the wood plank walls release heat longer into the living room and bedroom.

As far as Lammada house is concerned, the space under also has the largest percentage in calculating the length of time the air temperature is comfortable (70\%) with an average uncomfortable air temperature of $30^{\circ} \mathrm{C}$ or $0.6^{\circ} \mathrm{C}$ higher than the room under Jida house (Fig. 10). The living room and rooftop room have the lowest percentage of comfortable time, which is $58 \%$ with uncomfortable time during the day. Overall, the percentage of comfortable air temperature for the living room and bedroom of Lammada house (58\% and 62.5\%) is better than the same room at Jida house $(54 \%$ and $50 \%)$. This can be related to the difference in the peak air temperature of the living room and bedroom of Lammada house of 1 hour or lower compared to the same room in Jida house (2 hours).

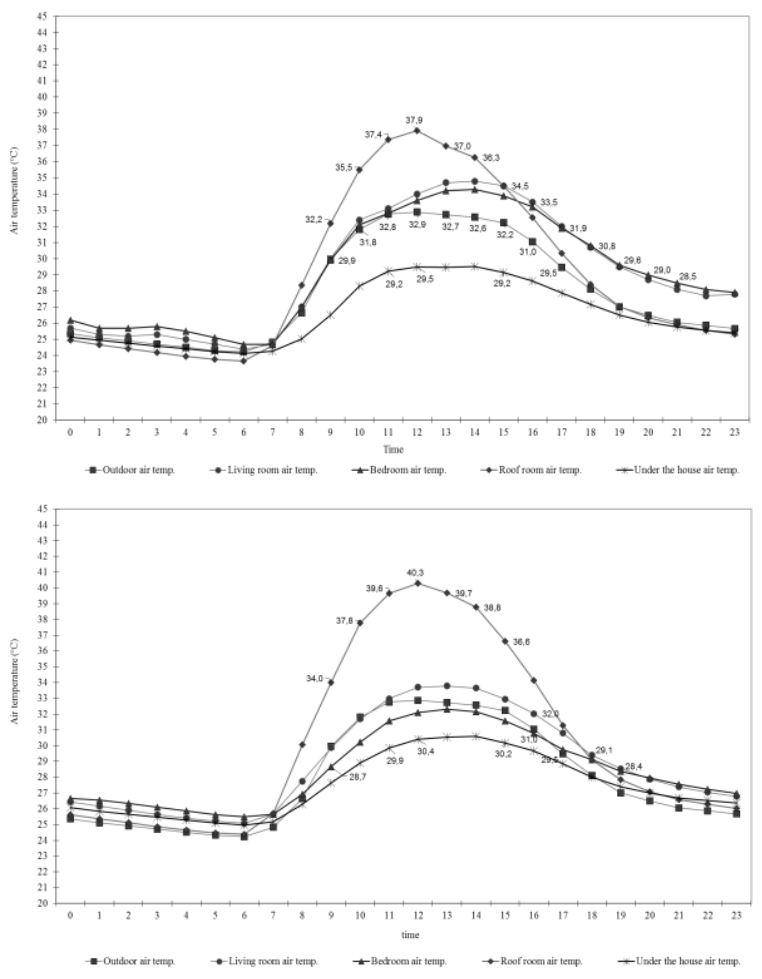

Fig. 9. Comparison of Air Temperatures in the Outdoor Room, Living Room, Bedroom, Roof Room and Room Under Jida House (above) and Lammada (bottom) to the Comfort Temperature Zone
The performance of decreasing air temperature can be calculated by reducing the temperature of the outside air with the temperature of the inside air, if the result is positive it is a temperature decrease, while if the result is negative, the indoor air temperature tends to increase. The largest decrease in air temperature in the Jida House occurred in the under room by $3.5^{\circ} \mathrm{C}$ at 09.00 and 11.00 and the average temperature decrease was $1.4{ }^{\circ} \mathrm{C}$ (Fig. 11 and 12). Similarly, such a decrease took place in Lammada house, the room under the room had the largest air temperature reduction performance $\left(3.9^{\circ} \mathrm{C}\right)$ or $0.4^{\circ} \mathrm{C}$ higher than Jida house, even though the average value of the decrease in air temperature was the same $\left(1.4^{\circ} \mathrm{C}\right)$. The decrease in air temperature began to occur significantly from 08.00 to 18.00 . The bedroom at Lammada house also has a better air temperature reduction performance than Jida house at 09.00 to 16.00 with an average decrease of $0.8^{\circ} \mathrm{C}$. One of the contributing factors is that the type of window that uses woven bamboo is able to reduce the incoming heat compared to the type of glass window.

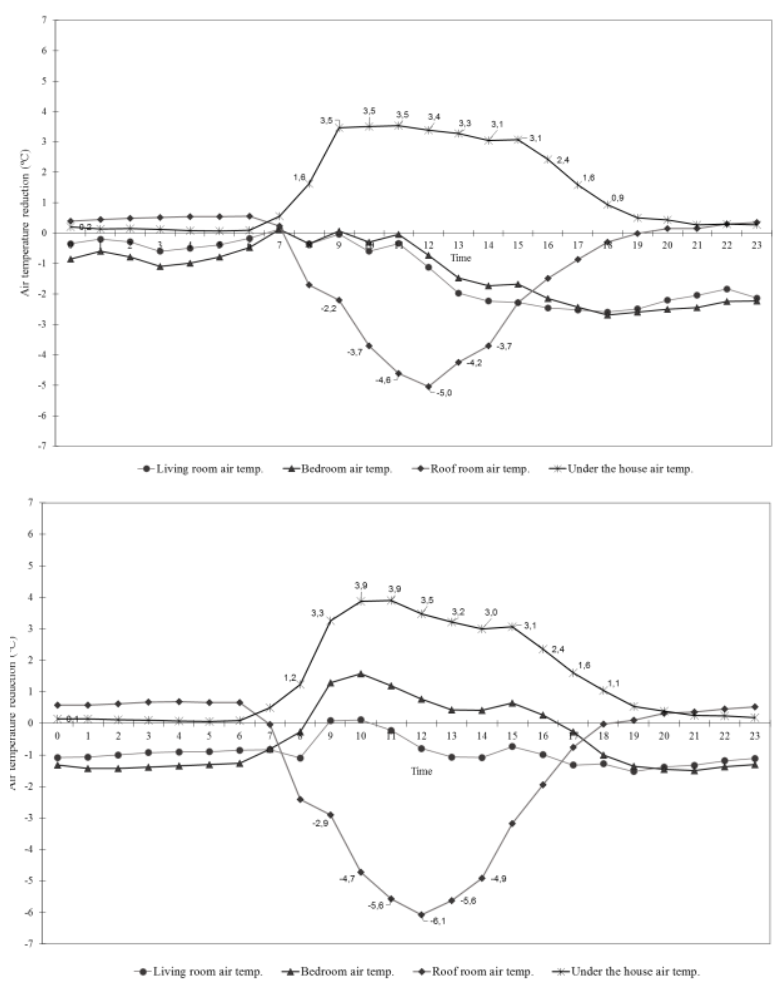

Fig. 10. Performance of Air Temperature Reduction in Living Room, Bedroom, Roof Room and Room Under Jida House (above) and Lambada (below)

Based on the general condition of the thermal environment as well as the performance of comfort and decreasing air temperature in the case study of the Bugis Vernacular House, it was found that Lammada House has a better thermal environmental perfor- 
mance than Jida house. This is indicated by the percentage of comfortable time in Lammada house's occupancy of $63 \%$ compared to $61 \%$ of the comfortable time of Jida house and there are two rooms of Lammada house that have a decrease in temperature during the day, i.e., in the bedroom and under the room. Based on the space, the space under both Jida House and Lammada House has the best temperature comfort with the lowest temperature magnitude and a longer percentage of time.

\section{Discussion of the results of visual observations and the performance of the thermal environment at Jida House and Lammada House}

The results of the thermal environmental performance of Lammada house are in accordance with the results of visual analysis, which states that a large roof volume is more climates responsive than the roof of Jida house. The large volume of the roof can maintain the heat exchange that enters the building as research by Daemei, A.B. et al., (2019). However, the roof of Lammada house is still not optimal with the temperature under the roof still not comfortable throughout the day. Based on visual observations, the change of roofing material is one of the causes of changes in the performance of the thermal environment. Zinc material has a higher thermal conductivity than thatch material and the absence of openings in the roof affects the heat accumulated in the roof space. This is in accordance with the opinion of Victoria et al., (2017) who stated the importance of openings in the roof to dissipate heat as in vernacular houses in Malaysia.

The comparison of the natural cooling performance of the two houses shows that the performance of reducing air temperature in the living room and bedroom of Lammada house is better than that of Jida house. While the visually distinguishing factor is the difference in the use of woven bamboo wall materials at Lammada house and wooden plank walls at Jida house. The woven bamboo walls allow air to flow in, remove hot air, and have a lower conductivity. The opinion of Prasetyo, (2016) which states that the use of materials with low conductivity can create thermal comfort in residential areas in coastal areas and the opinion of Nugroho, (2012) which explains that replacing woven bamboo with wooden boards will reduce the effectiveness of natural ventilation. The performance of decreasing air temperature in the bedrooms of Lammada house that is better than Jida house in the same room position is due to differences in the type and area of window openings. The use of glass windows with a larger area at the Jida House allows more solar radiation into the space. On the contrary, the Lammada House uses woven bamboo windows with a smaller area. This is in accordance with research by Hildegardis et al., (2019) which revealed that the use of natural materials will increase the natural cooling and ventilation of buildings and is reinforced by Nugroho, (2018) opinion regarding the effectiveness of the use of porous materials for hot air exchange.

The effect of floor height also affects the performance of reducing air temperature. The difference in floor height between Jida House and Lammada House is $50 \mathrm{~cm}$ resulting in a difference in maximum air temperature decrease of $0.4^{\circ} \mathrm{C}$. The higher the floor allows solar radiation to enter the space under the house and result in an increase in air temperature. However, further studies are still needed regarding the factors that affect the optimal floor height. As stated by Zune et al., (2020) that the effectiveness of floor heights needs to be combined with the type of floor material, and floor elevation in vernacular buildings allows cold air from below to replace hot air above it.

\section{CONCLUSION}

The conclusion answers the research objective, i.e., evaluating the performance of bioclimatic architecture in Bugis vernacular dwellings with case studies of Jida House and Lammada House in Pinrang Regency, South Sulawesi through aspects of visual observation and thermal environmental performance. Based on a visual study, it was found that the suitability of the bioclimatic design in Bugis vernacular housing is found in the large volume and slope of the roof; the type of porous walls, materials with low conductivity, floor heights and proper placement of shade plants on the west side of the building. Furthermore, aspects of the orientation of the sun and wind, the width and terrace of the building, and the number and size of window openings are quite appropriate. The performance of the thermal environment shows that Lammada house has better results than Jida house based on a greater percentage of the comfort zone in its residential space. The greatest decrease in air temperature was in the under room in each house with a maximum decrease of $3.9^{\circ} \mathrm{C}$ (Lammada house) and $3.5^{\circ} \mathrm{C}$ (Jida house). Bioclimatic elements that affect the decrease in air temperature are volume and roofing material, the type and material of the walls, and the height of the floor.

\section{ACKNOWLEDGMENT}

The author thanks Universitas Brawijaya Indonesia for the support through the Research Grant Scheme: "Hibah Penelitian Unggulan 2021 No.537. 18.2/UN10.C10/PN/2021" and Nur Rahma as Research Assistance. 


\section{REFERENCES}

Abdullah, A. M., Aziz, A. A., Ahmad, A. S., \& Mahdzar, S. S. S. (2013). Green technology: Comparison of thermal comfort levels for two traditional bugis houses in Malaysia. Advanced Science Letters, 19(12), 3512-3514. https://doi. org/10.1166/asl.2013.5208

Beccali, M., Strazzeri, V., Germanà, M. L., Melluso, V., \& Galatioto, A. (2018). Vernacular and bioclimatic architecture and indoor thermal comfort implications in hot-humid climates: An overview. Renewable and Sustainable Energy Reviews, 82, 1726-1736. https://doi.org/10.1016/ j.rser.2017.06.062

Daemei, A. B., Eghbali, S. R., \& Khotbehsara, E. M. (2019). Bioclimatic design strategies: A guideline to enhance human thermal comfort in $\mathrm{Cfa}$ climate zones. Journal of Building Engineering, 25. https://doi.org/10.1016/j.jobe.2019.100758

Dili, A. S., Naseer, M. A., \& Zacharia Varghese, T. (2011). Passive control methods for a comfortable indoor environment: Comparative investigation of traditional and modern architecture of Kerala in summer. Energy and Buildings, 43(23), 653-664. https://doi.org/10.1016/j.enbuild. 2010.11.006

Hildegardis, C., Agung Ayu Oka Saraswati, A., \& Ketut Agusinta Dewi, N. (2019). Review of Thermal Comfort in Warm Humid Climate for Traditional Architecture in Indonesia. KnE Social Sciences, 2019, 151-166. https://doi.org/ 10.18502/kss.v3i21.4965

Manzano-Agugliaro, F., Montoya, F. G., SabioOrtega, A., \& García-Cruz, A. (2015). Review of bioclimatic architecture strategies for achieving thermal comfort. Renewable and Sustainable Energy Reviews, 49, 736-755. https://doi.org/ 10.1016/j.rser.2015.04.095
Nguyen, A. T., Tran, Q. B., Tran, D. Q., \& Reiter, S. (2011). An investigation on climate responsive design strategies of vernacular housing in Vietnam. Building and Environment, 46(10), 2088-2106. https://doi.org/10.1016/j.buildenv. 2011.04.019

Nguyen, A. T., Truong, N. S. H., Rockwood, D., \& Tran Le, A. D. (2019). Studies on sustainable features of vernacular architecture in different regions across the world: A comprehensive synthesis and evaluation. Frontiers of Architectural Research, 8(4), 535-548. https://doi.org/10.1016 /j.foar.2019.07.006

Nugroho, A. M. (2012). A Thermal Assessment of the Traditional House In Flores, Indonesia. J. Basic. Appl. Sci. Res., 2(12), 12795-12801.

Nugroho, A. M. (2018). Arsitektur Tropis Nusantara: Rumah Tropis Nusantara Kontemporer. UB Press, Malang.

Nugroho, A. M. (2019). Rekayasa Ventilasi Alami Untuk Penyejukan Bangunan sebagai Wujud Kecerdasan Dasar Arsitektur Nusantara. UB Press, Malang.

Prasetyo, Y. H. (2016). Analisis Kinerja Termal dan Aerodinamis pada Rumah Tradisional Batak Toba Menggunakan Simulasi Digital dan Pengukuran Lapangan. Widyariset, 2(2), 131-142.

Prasetyo, Y. H., \& Astuti, S. (2017). Ekspresi Bentuk Klimatik Tropis Arsitektur Tradisional Nusantara dalam Regionalisme. Jurnal Permukiman, 12(2), 80-93.

Victoria, J., Mahayuddin, S. A., Zaharuddin, W. A. Z. W., Harun, S. N., \& Ismail, B. (2017). Bioclimatic Design Approach in Dayak Traditional Longhouse. Procedia Engineering, 180, 562570. https://doi.org/10.1016/j.proeng.2017.04.215

Zune, M., Rodrigues, L., \& Gillott, M. (2020). Vernacular passive design in Myanmar housing for thermal comfort. Sustainable Cities and Society, 54, 101992. https://doi.org/10.1016/j.scs. 2019.101992. 